\title{
Nominācijas, avansējumi un godinājumi Latvijas medicīnā: 2001.-2011. gads
}

Apkopotas ziņas par ārstiem, kas saṇēmuši valsts apbalvojumus (ordeņus un ordeņu goda zīmes), Ministru kabineta balvu, Latvijas Ārstu biedrības apbalvojumus, kā arī vairāku iestāžu un nevalstisko organizāciju apbalvojumus (Paula Stradiņa balvu, Kristapa Rudzīša balvu, Ilmāra Lazovska balvu, Jēkaba Prīmaņa balvu, Dāvida Hieronīma Grindel̦a medaļu, Latvijas Sarkanā Krusta Goda krustu). Sniegti dati par ārstiem, kas aizstāvējuši medicīnas doktora disertāciju vai kam piešksirts goda doktora grāds. Minēti ārsti, kas ievēlēti par profesoriem, asociētajiem profesoriem vai Latvijas Zinātņu akadēmijas locekḷiem, kā arī tie, kam piešksirts valsts emeritētā zinātnieka nosaukums. Sistematizēti dati par ārstiem - Saeimas deputātiem, veselības ministriem un ārstiem divos valsts augstākajos amatos.

Aptverts 21. gadsimta sākums, proti, no 2001. gada, turklāt norādīts vai nu apbalvojuma piešksiršanas, grāda un nosaukuma iegūšanas, vai arī amatā stāšanās gads. ${ }^{1}$

Personālijas shēma: vārds, uzvārds, dzimšanas gads (vai dzīves gadi), specialitāte. Sarakstos ietverti galvenokārt akadēmisku izglītību guvuši ārsti, kā arī daži farmaceiti, veterinārārsti, feldšeri, medicīnas māsas, laboranti u. c. kategoriju mediksi. ${ }^{2}$

1 Amatā stāšanās gads minēts Saeimas deputātiem, Valsts prezidentam un veselības ministriem.

2 Ziṇas smeltas no šādiem avotiem: Latvijas Triju Zvaigžņu ordenis: 1994-2004. Rīga, 2004. - 68 lpp.; Valsts emeritēto zinātnieku saraksts: Zinātne un mana dzīve. - 1. sēj. - Rīga, [2009], 458.-467. lpp.; Vīksna A. Latvijas Republikas medicīnas un farmācijas zinātnieki 1992-2005: Rādītājs. - Rīga, 2005. - 35 lpp. 
Dažos gadījumos neizdevās iegūt visus nepieciešamos datus, kas turpmāk precizējami. Teksts tika sagatavots 2012. gadā, pēdējie precizējumi (galvenokārt miršanas gadi) veikti 2016. gada jūlijā.

Par palīdzību datu piln̄̄gošanā pateicos Jānim Lojam un Valdai Rupertei-Rolai. ${ }^{3}$

\section{Triju Zvaigžṇu ordenis, \\ 1. šķira un ķēde}

2008

Valdis Zatlers (1955), ķirurgs, veselības aprūpes vadītājs.

\section{Triju Zvaigžṇu ordenis,}

2. šksira

\section{1}

Gundars Daudze (1965), anesteziologs reanimatologs.

\section{Triju Zvaigžn̦u ordenis,}

\section{4. šksira}

\section{1}

Guntis Siliņš (1950-2015), ārsts, sabiedrisks darbinieks (Kanāda); Kārlis Zvejnieks (1921), ārsts, rakstnieks (ASV).

\section{2}

Kaspars Tūters (1937), psihiatrs (Kanāda);

Vaida Villeruša (1930-2009), ķirurǵe.

\section{3}

Andrejs Ērglis (1964), kardiologs;

Uldis Kalniņš (1946-2004), kardiologs;

3 Jānis Loja - medicīnas tekstu literārais redaktors, Valda Ruperte-Rola - medicīnas māsa, strādājusi par Latvijas Ārstu biedrības sekretāri, Sarkanā Krusta medicīnas koledžas docētāju. 
Jānis Priedkalns (1934), morfologs;

Mārtiņš Šics (1950), veselības aprūpes vadītājs;

Kristaps Kristofers Zariņš (1943), angioķirurgs (ASV).

\section{4}

Romans Lācis (1946), kardioķirurgs;

Baiba Rozentāle (1955), infekcioniste;

Uldis Vikmanis (1943), onkologs;

Bertrams Zarin̦š (1942), ortopēds (ASV).

\section{5}

Andris Saltups (1935), kardiologs (Austrālija).

\section{6}

Anatolijs Bḷugers (1926-2007), hepatologs;

Ivars Siliņš (1931), internists.

\section{7}

Māris Andersons (1946), ftiziopneimonologs, veselības aprūpes vadītājs;

Gaida Krūmiņa (1946), neiroradioloǵe;

Jānis Vētra (1959), biomehāniķis;

Arnis Vīksna (1942), medicīnas vēsturnieks;

Valdis Zatlers (1955), ķirurgs, veselības aprūpes vadītājs.

\section{8}

Viesturs Boka (1948), ķirurgs, veselības aprūpes vadītājs;

Bencions Cerlıks (1913-2009), traumatologs ortopēds;

Līga Cīrule (1961), sporta ārste;

Laimonis Aleksandrs Ejubs (1930), traumatologs ortopēds;

Voldemārs Lejiņš (1957), ginekologs.

\section{9}

Dzintars Mozgis (1958), bērnu ķirurgs, veselības aprūpes vadītājs;

Edmunds Rudzītis (1942-2010), narkologs;

Ludmila Vīksna (1946), infektoloǵe. 
Ausma Bērziņa (1925-2010), anatome;

Maija Eglīte (1939), arodpatoloǵe;

Rita Kukaine (1922-2011), virusologie;

Uldis Laucis (1936-2013), veselības aprūpes vadītājs;

Leopolds Ozoliņš (1937), traumatologs ortopēds.

2011

Arnolds Atis Veinbergs (1942), radiologs.

\section{Triju Zvaigžņu ordenis,}

\section{5. škira}

\section{1}

Egons Daugulis (1934-2010), anesteziologs reanimatologs;

Visvaldis Georgs Nagobads (1921), sporta ārsts (ASV);

Rafails Rozentāls (1937), transplantologs.

\section{2}

Nikolajs Andrejevs (1930-2002), kardiologs;

Guna Dambīte (1922-2009), oftalmoloǵe;

Helmi Fogele-Rožankovska (1922-2013), zobārste (ASV);

Aina Galēja-Dravniece (1925-2013), patoloğe (ASV);

Jānis Grīmbergs (1926), zobārsts (Braz̄ilija);

Ilze Knezinska-Švarce (1935), psihiatre (ASV);

Viesturs Krūmiņš (1952), onkologs;

Gunārs Lasmanis (1957), onkologs;

Jānis Leimans (1942-2014), torakālais ķirurgs;

Mihails Malkiels (1932), kurortologs;

Ansis Muižnieks (1928), internists.

\section{3}

Jānis Bicāns (1945), nefroķirurgs;

Enoks Biķis (1937), pediatrs;

Māra Godḷevska (1943-2008), neiroloǵe; 
Sigurds Oto Krolls (1931), orālpatologs (ASV);

Andris Ritmanis (1926), ārsts (ASV);

Agnis Štifts (1923), endokrinologs.

\section{4}

Dzintra Jakubaņeca (1959), ātrās palīdzības ārste.

\section{5}

Marta Aizsilniece (1939), veselības aprūpes vadītāja;

Jānis Dobelis (1943), bērnu ķirurgs;

Eva Platkāja (1939), pediatre;

Andrejs Spandegs (1936), internists.

\section{6}

Raisa Andrēziņa (1938), psihiatre;

Māris Mihelsons (1936-2014), ķirurgs;

Jānis Sokolovs (1943), otolaringologs.

\section{7}

Harijs Knesis (1955), anesteziologs reanimatologs;

Dace Matule (1961), ginekoloğe;

Juris Vìtols (1943), ginekologs;

Līga Zvaigzne (1957), interniste.

\section{8}

Andrejs Skaǵers (1940), kirurgs.

\section{9}

Vilis Mileiko (1932), ğimenes ārsts (Kanāda);

Dzintars Ronalds Paegle (1936), ārsts (ASV).

2010

Ilga Urtāne (1950), zobārste. 


\section{Triju Zvaigžņu ordeṇa \\ zelta goda zīme}

\section{1}

Aivars Enkūzens (1942), bronhologs;

Vaira Leimane (1944), ftiziopneimonoloǵe;

Džons Džozefs Makdermots (1932 -2013), oftalmologs (ASV);

Ieva Paegle (1942), neiroloǵe;

Jana Savdona (1939), veselības aprūpes vadītāja;

Zigfrīds Zadvinskis (1924), ārsts, sabiedrisks darbinieks (ASV).

\section{2}

Zaiga Priede-Kalniņa (1938), māszin̄̄bu speciāliste (ASV);

Arnolds Valtneris (1929-2003), fiziologs.

\section{3}

Ciemalda Lūkina (1932), uroloǵe;

Ilga Volosova (1926-2009), ftiziatre.

\section{4}

Gunārs Grīnbergs (1930), endoskopists; Anna Krilova (1939), onkoloǵe.

\section{Triju Zvaigžņu ordeṇa sudraba goda zīme}

2001

N̦ina Medne (1926-2009), ftiziopneimonoloǵe;

Jolanta Zariņa (1927), ftiziopneimonoloǵe.

\section{2}

Herta Annemarija Salceviča (1932 -2016), interniste. 


\section{Viestura ordenis, 1. šķira}

2008

Valdis Zatlers (1955), ķirurgs, veselības aprūpes vadītājs.

\section{Viestura ordenis, 3. šksira}

2007

Mārtiņš Šics (1950), veselības aprūpes vadītājs.

\section{Viestura ordenis, 4. šksira}

2004

Edgars Maskalāns (1955), militārārsts.

\section{5}

Valdis Mednis (1943), ķirurgs.

\section{7}

Jānis Turks (1964), militārārsts.

\section{Viestura ordenis, 5. šķira}

2005

Ojārs Uldis Aleksis (1923), ķirurgs.

2007

Benita Feldmane (1937), ķirurğe.

\section{Atzinības krusts, 1. škşira \\ 2008}

Valdis Zatlers (1955), ķirurgs, veselības aprūpes vadītājs. 


\section{Atzinības krusts, 2. šḳira}

\section{5}

Nikolajs Skuja (1913-2012), internists.

\section{Atzinības krusts, 4. šķira}

\section{5}

Aina Muceniece (1924-2010), virusologie;

Rojs Peršons, psihiatrs (Zviedrija).

\section{6}

Lauma Cipele (1935), pediatre.

\section{7}

Dace Gardovska (1952), pediatre;

Aigars Pētersons (1959), bērnu ķirurgs;

Ingrīda Rumba (1959), pediatre.

\section{8}

Valda Buzijana (1945), zobārste, veselības aprūpes vadītāja;

Sandra Kuškse (1966), otolaringolog̣e;

Anita Lapina (1953), gastroenteroloğe;

Mārtiņš Liepiņš (1943), ķirurgs;

Ilga Astrīda Mežale (1938), anestezioloǵe reanimatoloǵe;

Iveta Ozolanta (1948), biomehāniḳe.

\section{9}

Pēteris Apse (1942), zobārsts;

Inese Bunga (1958), veselības aprūpes vadītāja;

Mintauts Caune (1929), psihiatrs;

Anita Gaigala (1948), interniste;

Mārtiņš Rempe (1936), veselības aprūpes vadītājs;

Antoṇina Sondore (1936), anestezioloğe reanimatoloğe. 
Biruta Kupča (1939), psihiatre;

Viktorija Linaberga (1937), rehabilitologe;

Ivars Ūpis (1939), traumatologs ortopēds;

Iljja Zake (1953), kardiologs.

\section{1}

Biruta Barkāne (1935), ķirurǵe stomatoloǵe;

Tatjana Ešenvalde (1950), veselības aprūpes vadītāja;

Georgijs Jankovskis (1921), fiziologs;

Jāzeps Keišs (1942), infekcionists;

Pēteris Kučāns (1945-2016), internists;

Pēteris Studers (1958), traumatologs ortopēds.

\section{Atzinības krusts, 5. šķira}

\section{5}

Zaiga Alksne-Filipsa (1934), pediatre (ASV);

Vairis Jēkabsons (1938), ķirurgs;

Gita N̦emceva (1940), veselības aprūpes vadītāja.

\section{7}

Helēna Bergmane (1930), ginekoloğe;

Rolands Gibners (1958), ortopēds;

Juris Mangulis (1922-2009), ǵimenes ārsts (ASV);

Baiba Paije (1942), ginekoloǵe;

Vitālijs Zvirgzdiņšs (1952), angioķirurgs.

\section{8}

Jānis Baumanis (1941), ortopēds (Kanāda);

Jānis Jāzeps Dimants (1937), ginekologs (ASV);

Vaclavs Jasvins (1950), zobārsts;

Guna Tetere (1958), kardioķirurǵe. 
Staņislavs Lubāns (1915-2010), ķirurgs;

Gaida Rita Sinka (1929), bērnu alergoloǵe;

Astrīda Tirāne (1942), ginekoloğe endokrinoloǵe.

\section{0}

Vija Bērziņa (1937), onkoloǵe;

Dzintra Celmina (1945), pediatre;

Kamena Kaidaka (1962), pediatre.

\section{1}

Ilona Balode (1965), pediatre;

Māra Girgensone (1943-2012), bioķīmiķe;

Marina Sevastjanova (1940), ķirurğe stomatoloǵe;

Helēna Biruta Štāle (1938), onkoloğe citoloǵe.

\section{Atzinības krusta \\ lielā sevišksās pakāpes goda zīme}

2005

Zinaida Kasvande (1934-2012), sporta ārste;

Gunārs Kiršbergs (1932), neirologs;

Egils Pēteris Krastiņš (1934), anesteziologs reanimatologs.

\section{6}

Ārija Caurkubula (1935), pediatre;

Inese Valeiņa (1937), bērnu oftalmoloǵe.

2009

Ludmila Ivanova (1939), oftalmoloǵe.

\section{Atzinības krusta}

mazā sevišksās pakāpes goda zīme

2005

Marija Liepiņa (1942), bērnu ķirurğe;

Ausma Paļakauska (1937), ātrās palīdzības ārste. 


\section{Atzinības krusta \\ zelta goda zīme \\ 2005}

Vladimirs Januškevičs (1940), onkologs;

Ārija Marksa-Ebela (1941), bērnu gastroenteroloǵe;

Anatolijs Ruskulis (1955), internists.

\section{Ministru kabineta balva}

2002

Romans Lācis (1946), kardioķirurgs.

\section{5}

Jānis Gardovskis (1955), ķirurgs.

2006

Andrejs Ērglis (1964), kardiologs.

2007

Marija Liepiṇa (1942), bērnu ķirurğe.

2009

Aris Lācis (1936), kardioķirurgs.

2010

Rafails Rozentāls (1937), transplantologs.

\section{Latvijas Ārstu biedrības goda biedrs}

\section{1}

Jūlijs Anšelevičs (1931-2004), internists; Anatolijs Blıgers (1926-2007), hepatologs;

Dzidra Branta (1927), dermatoveneroloǵe;

Ilmārs Lazovskis (1931-2003), internists; Alfrēds Miltiņš (1939), dermatovenerologs;

Ivars Siliņš (1931), internists. 
Mirdza Rošonoka (1928-2014), citoloǵe;

Rasma Volkolākova (1930), oftalmoloğe.

\section{3}

Jānis Zālītis (1933-2007), psihoterapeits, onkologs.

\section{6}

Mintauts Caune (1929), psihiatrs.

\section{7}

Ojārs Uldis Aleksis (1923), ķirurgs;

Georgs Andrejevs (1932), anesteziologs reanimatologs;

Enoks Biķis (1937), pediatrs;

Velta Bramberga (1921-2012), onkoloǵe;

Jānis Dimants (1937), ğimenes ārsts;

Ernests Gaudiņš (1922-2008), otolaringologs;

Jānis Gaujēns (1932), bērnu ķirurgs;

Viktors Kalnbērzs (1928), ķirurgs;

Miervaldis Kaminskis (1922-2011), anatoms;

Vilis Krasts (1917-2009), dermatovenerologs;

Ruta Krievkalne (1927), medicīnas statistiķe;

Mihails Malkiels (1932), kurortologs;

Modris Melzobs (1927-2014), farmakologs;

Elza Preimate (1920-2015), interniste;

Vija Rozīte (1930), anestezioloǵe reanimatologe;

Agnis Štifts (1923), endokrinologs;

Vilens Tolpežñikovs (1928-2008), radiologs;

Jānis Volkolākovs (1931), kardioķirurgs;

Antons Zvīdris (1932), ftiziatrs.

\section{8}

Ausma Bērziña (1925-2010), anatome;

Juris Bērziņš (1928), neirologs;

Milda Endzelīna (1918-2009), interniste; 
Ģertrūde Eniņa (1926), neirolog̣e;

Ēvalds Ezerietis (1913-2013), kirurgs;

Ansis Muižnieks (1928), internists;

Jevgeñijs Nemiro (1926-2012), rentgenologs;

Anatolijs N̦ikitins (1928), ķirurgs;

Haralds Voskis (1928-2011), ķirurgs anatoms.

\section{9}

Uldis Arents (1929-2015), ķirurgs;

Kārlis Auškāps (1925-2012), internists;

Natālija Bāliņa (1925), ķirurğe;

Anita Caune (1930), ginekoloğe;

Bencions Cerluks (1913-2009), traumatologs ortopēds;

Tamāra Čēma (1920), bērnu ķirurgé;

Zenta Lilija Dāboliņa (1922-2011), interniste;

Janīna Danusēviča (1928-2016), anatome, redaktore;

Bruno Grasis (1927), ķirurgs;

Erna Grāvīte (1926), zobārste;

Haralds Jansons (1934), biomehāniķis;

Dzidra Kalniņa (1924-2015), ǵimenes ārste;

Kristaps Kegi (1934), ortopēds (ASV);

Gunārs Kiršbergs (1932), neirologs;

Jānis Liepiņš (1930), dietologs;

Oḷǵerts Marga (1929), ftiziatrs;

Arvīds Pakalns (1919), ķirurgs;

Andris Saltups (1934), kardiologs (Austrālija);

Semjons Štrihs (1934-2015), veselības aprūpes vadītājs;

Lūcija Treimane (1925), zobārste;

Kaspars Tūters (1937), psihoterapeits (Kanāda);

Skaidrīte Valdovska (1924), interniste;

Pāvils Vasariņšs (1928), dermatologs (Kanāda);

Egils Vēverbrants (1935), nefrologs (ASV);

Vaida Villeruša (1930-2009), ķirurǵe, novadpētniece;

Ërika Zaķe (1923), traumatoloğe ortopēde. 
Skaidrīte Ādamsone (1937), interniste;

Zaiga Alksne-Filipsa (1934), pediatre (ASV);

Arnis Amoliņš (1930-2014), radiologs;

Edgars Brēmanis (1935), sporta ārsts;

Jānis Cērps (1932-2015), internists;

Guntis Cēsnieks (1935), neirologs;

Uldis Eimuss (1935), radiologs;

Pāvels Ivdra (1935-2012), urologs;

Klāra Kondrova (1932), ķirurǵe;

Jānis Lācis (1935), kardiologs;

Aina Nagobada-Ābola (1920), zobārste, diplomāte (Francija);

Edvīns Platkājis (1938), veselības aprūpes vadītājs;

Gunārs Purmalis (1935), ķirurgs;

Ainārs Rudziņš (1937), ǵimenes ārsts;

Jānis Strods (1931), ķirurgs;

Velta Volksone (1931), tiesu medicīnas eksperte;

Aivars Zirnis (1935-2015), anesteziologs reanimatologs.

\section{1}

Voldemārs Brauns (1921-2016), internists;

Gunta Geldnere (1936), gastroenteroloǵe;

Iveta Grapa-Grāfa (1939), interniste;

Rasma Heniña (1933), radioloǵe;

Georgijs Jankovskis (1921), fiziologs;

Rasma Kalniņa (1932-2016), homeopāte;

Edīte Lazovska (1932), ginekoloǵe;

Māris Mihelsons (1936-2014), ķirurgs;

Visvaldis Nagobads (1921), sporta ārsts (ASV);

Marija Poikāne (1934-2012), endokrinoloǵe;

Rita Putniņa (1924), interniste;

Dzidra Ieva Užāne (1937), interniste;

Juris Galerijs Vidiņš (1938), veselības aprūpes vadītājs. 


\section{Latvijas Ārstu biedrības \\ I pakāpes goda zīme "Cilvēka laiks" \\ (Tempus hominis)}

2009

Viktors Kalnbērzs (1928), ķirurgs;

Kristaps Kegi (1934), ortopēds (ASV);

Bertrams Zariņš (1942), ortopēds (ASV).

2010

Dena Hensons, dermatologs (Kanāda); Jānis Vētra (1959), biomehāniķis.

\section{Latvijas Ārstu biedrības \\ II pakāpes goda zīme "Cilvēka laiks"}

(Tempus hominis)

2009

Marta Aizsilniece (1939), veselības aprūpes vadītāja;

Tamāra Čēma (1920), bērnu ķirurǵe;

Ģertrūde Eniņa (1926), neiroloğe;

Elkonons Goldbergs, psihiatrs (ASV);

Vilnis Grīnbergs (1961), anesteziologs reanimatologs;

Egils Krastiņš (1934), anesteziologs reanimatologs;

Ivars Krastiņš (1955), anesteziologs reanimatologs;

Sandra Lejniece (1963), hematologe;

Aigars Migals (1952), radiologs;

Jevgenijis Nemiro (1926-2012), rentgenologs;

Mihails Perelmans (1924-2013), ftizioķirurgs (Krievija);

Rafails Rozentāls (1937), transplantologs;

Vilnis Sosārs (1956), onkologs;

Georgs Šiliņ̌̌ (1918-2012), endokrinologs;

Agnis Štifts (1923), endokrinologs;

Arnis Vīksna (1942), medicīnas vēsturnieks. 
Georgs Andrejevs (1932), anesteziologs reanimatologs;

Irēna Beimane (1949), oftalmoloğe;

Vija Cera (1936), anestezioloǵe reanimatoloǵe;

Laimonis Ejubs (1930), traumatologs ortopēds;

Edvards Hills (1938), ǵimenes ārsts (ASV);

Jautrīte Karaškevica (1945-2011), veselības aprūpes vadītāja;

Otmārs Kloibers, patofiziologs (Vācija);

Biruta Kupča (1939), psihiatre;

Liutaurs Labanausks (1960), pediatrs (Lietuva);

Andruss Mēsalu (1956), ķirurgs (Igaunija);

Jānis Raibarts (1939), internists;

Antonina Sondore (1936), anestezioloǵe reanimatoloǵe;

Aivars Stengrevics (1933), onkologs;

Viesturs Šiliņš (1950), ftiziopneimonologs;

Valentīns Šloss (1922), veterinārārsts (Austrālija);

Marta Veita (1941), interniste.

\section{1}

Romualds Daudze (1941), anesteziologs reanimatologs;

Vilnis Dzērve-Tāluts (1941), fiziologs;

Vilis Grabausks (1942), kardiologs (Lietuva);

Vija Grigale (1948), ātrās palīdzības ārste;

Astrīda Igolniece (1948), ātrās palīdzības ārste;

Aleksandrs Jevtušoks (1952), veselības aprūpes vadītājs;

Gunta Kluce (1951), hematoloǵe;

Žanna Kovaļova (1965), pediatre;

Lidija Muceniece (1941), veselības aprūpes speciāliste;

Māris Pḷaviņš (1951), nefrologs;

Murmans Ratiani (1947), onkologs;

Ulrihs Sigvarts (1941), kardiologs (Vācija);

Ivars Siliņš (1931), internists;

Nikodēms Sparāns (1939), ķirurgs;

Edgars Stankevičs (1972), kardioķirurgs (Lietuva);

Arnolds Atis Veinbergs (1942), radiologs;

Remīgijs Žaļūns (1961), kardiologs (Lietuva). 


\section{Paula Stradina balva}

\section{1}

Viktors Kalnbērzs (1928), ķirurgs;

Juris Salaks (1961), medicīnas vēsturnieks.

\section{2}

Jānis Volkolākovs (1931), ķirurgs.

\section{3}

Jānis Vētra (1959), biomehāniksis.

2004

Anatolijs Bḷugers (1926-2007), hepatologs.

\section{5}

Valdis Jākobsons (1938), ekonomists;

Krista Habriha (1940-2013), farmakoloǵe, medicīnas vēsturniece(Vācija).

2006

Andrejs Skağers (1940), ķirurgs.

\section{7}

Edvīns Platkājis (1938), veselības aprūpes vadītājs.

\section{8}

Ēvalds Ezerietis (1913-2013), ķirurgs;

Bertrams Zariņš (1942), ortopēds (ASV).

\section{9}

Jānis Gaujēns (1932), bērnu ķirurgs;

Fēlikss Ungers (1946), ķirurgs (Austrija).

\section{0}

Jānis Gardovskis (1955), ķirurgs.

\section{1}

Lembits Allikmets (1936), farmakologs (Igaunija). 


\section{Kristapa Rudzǐša balva}

2001

Nikolajs Skuja (1913-2012), internists.

\section{Ilmāra Lazovska balva}

2011

Andrejs Kalvelis (1940), kardiologs.

\section{Jēkaba Prīmaṇa balva}

2001

Nikolajs Cauna (1914-2007), anatoms (ASV);

Aina Dālmane (1926-2014), histoloğe;

Genovefa Jēča (1921-2011), anatome;

Rūta Lindberga (1926-2009), anatome.

2007

Kārlis Ēriks Arons (1933-2005), medicīnas vēsturnieks;

Staņislavs Lubāns (1915-2010), ķirurgs.

\section{Dāvida Hieronīma Grindel̦a medaḷa}

\section{1}

Pēteris Apinis (1958), anesteziologs reanimatologs, publicists; Indulis Purviņš (1947), farmakologs.

\section{2}

Viesturs Baumanis (1942-2013), molekulārbiologs.

2003

Jānis Baltkājs (1935), farmakologs.

\section{6}

Anatolijs Bḷugers (1926-2007), hepatologs.

\section{7}

Rolfs Martins Cinkernāgels (1944), imunologs (Šveice);

Ināra Rubene (1960), nefroloǵe. 


\section{Latvijas Sarkanā Krusta Goda krusts}

2007

Guntis Belēvičs (1958), biofiziķis, farmaceits.

\section{Medicīnas doktors (Dr. med.)}

\section{1}

Nataļja Kurjāne (1970), arodpatoloǵe.

\section{2}

Aigars Lācis (1961), ķirurgs;

Ardis Platkājis (1964), radiologs.

\section{3}

Edmunds Austrums (1971), kुirurgs;

Māris Bukovskis (1971), alergologs;

Ilva Duļevska (1949), anatome;

Juris Ërenpreiss (1975), andrologs;

Gundega Jākobsone (1970), stomatologe;

Dace Klincāre (1963), kardiolog̣e;

Mārcis Leja (1964), gastroenterologs;

Andrejs Millers (1959), neirologs;

Vladimirs Skḷarevičs (1967), rehabilitologs;

Aivars Vētra (1956), rehabilitologs.

\section{4}

Guntis Bahs (1967), kardiologs;

Sandra Bērziņa (1965), stomatologie;

Inese Folkmane (1961), nefroloğe;

Arvīds Irmejs (1973), ķirurgs;

Baiba Jansone (1974), farmakologe;

Andra Liepa (1970), stomatoloǵe;

Aigars Martinsons (1971), kirurgs;

Dzintars Mozgis (1958), bērnu ķirurgs;

Maija Pozemkovska (1966), vēsturniece;

Pēteris Stradiṇš (1971), kardioķirurgs; 
Egils Vjaters (1963), urologs;

Vita Zīdere (1968), bērnu kardioloǵe;

Tija Zvagule (1956), arodpatoloǵe.

\section{5}

Andra Dērveniece (1974), dermatoveneroloğe;

Arnolds Kadišs (1975), ķirurgs;

Oskars Kalējs (1957), kardiologs;

Jautrīte Karaškevica (1945-2011), sabiedrības veselības speciāliste;

Evija Miglāne (1970), neiroloǵe;

Zenons Narbuts (1971), ķirurgs;

Iveta Ozere (1958), ftiziopneimonologe;

Aivars Pētersons (1956), nefrologs;

Santa Purviņa (1972), farmakologe;

Vija Riekstina (1971), ftiziopneimonolog̣e;

Ženija Roja (1947), arodpatoloǵe;

Ilze Štrumfa (1974), patoloǵe;

Māris Taube (1974), psihiatrs.

\section{6}

Andrejs Ërglis (1964), kardiologs;

Ilze Grope (1967), bērnu infekcioniste;

Inese Kolontaja (1976), dermatovenerologe;

Uldis Kopeika (1972), ķirurgs;

Angelika Krūmiņa (1970), infekcioniste;

Gustavs Latkovskis (1971), kardiologs;

Vilnis Lietuvietis (1962), ķirurgs;

Inguna Lubaua (1967), bērnu kardioloǵe;

Vitolds Mackevičs (1956), internists;

Dace Rezeberga (1960), ginekoloǵe;

Ināra Roja (1946), hipnoterapeite;

Silvija Umbraško (1952), anatome;

Agnis Zvaigzne (1974), endokrinologs;

Sanita Žīgure (1968), dermatoveneroloğe. 
Zane Ābola (1977), bērnu ķirurǵe;

Aurika Babjoniševa (1968), interniste;

Ilva Daugule (1971), pediatre;

Jānis Eglītis (1969), onkologs;

Ieva Henkuzena (1961), zobārste;

Jānis Jušinskis (1972), ķirurgs;

Linda Klimaviča (1972), farmakoloǵe;

Sandra Kuškse (1966), otolaringoloǵe;

Baiba Lāce (1974), ǵenētiķe;

Inguna Rence-Bambīte (1966), stomatoloğe;

Raimonds Sīmanis (1966), infekcionists;

Aiga Stāka (1971), gastroenteroloǵe;

Uldis Strazdiņš (1965), kardioķirurgs;

Ieva Strēle (1973), endokrinoloǵe;

Eva Strīķe (1968), anestezioloǵe reanimatoloǵe;

Anita Vētra (1953), rehabilitoloǵe;

Jūlija Voicehovska (1966), interniste;

Indra Zeltiņa (1972), infekcioniste;

Līga Zvejniece (1974), farmakoloǵe;

Guntis Žīgurs (1953), stomatologs.

\section{8}

Andris Gardovskis (1981), ķirurgs;

Sandra Gintere (1966), gimenes ārste;

Alinta Hegmane (1974), onkoloǵe;

Arnolds Jezupovs (1971), ķirurgs;

Guntis Karelis (1973), neirologs;

Ilze Konrāde (1972), endokrinoloǵe;

Lija Lauriņa (1955), zobārste;

Inta Liepniece-Karele (1973), onkoloǵe;

Inta Macāne (1975), neiroloğe;

Linda Matisāne (1973), arodpatoloǵe;

Zaiga Nora, virusoloǵe;

Jolanta Pugača (1977), ortodonte; 
Māra Rone-Kupfere (1973), dermatoloǵe;

Kristīne Rozniece (1974), dermatoveneroloǵe;

Silvestrs Rubins (1973), dermatovenerologs;

Maija Rumaka (1973), fizioloǵe;

Gunta Stūre (1969), infekcioniste;

Rodrigo Sveržickis (1970), neiroksirurgs;

Ivars Tolmanis (1965), gastroenterologs;

Ivars Vanadziņš (1974), arodpatologs.

\section{9}

Zane Gaile (1962), rehabilitoloǵe;

Iveta Golubovska (1965), anestezioloǵe reanimatoloǵe;

Simons Gribausks, zobārsts (Lietuva);

Jekaterina Gudkina (1974), zobārste;

Sergejs Isajevs (1981), patologs;

Dzintra Kažoka (1974), morfoloǵe;

Iveta Kudaba (1965), onkoloǵe;

Kārlis Kupčs (1969), radiologs;

Viktorija Kuzema (1975), nefroloǵe;

Inga Lāce (1970), bērnu kardioloǵe;

Toms Linkevičs, zobārsts (Lietuva);

Ilans Lisagors (1975), anesteziologs reanimatologs;

Inese Mauliņa (1952), zobārste;

Anita Oginska (1961), pediatre;

Henrijs Ozoliņš (1963), neiroķirurgs;

Gunta Purkalne (1946), onkoloǵe;

Antra Ragauska (1973), zobārste;

Ilze Šalma (1971), anestezioloǵe reanimatoloǵe;

Olga Utehina (1974), onkoloǵe.

\section{0}

Andris Ābeltiņš (1979), zobārsts;

Zeltīte Cederštrēma (1968), morfoloǵe;

Sergejs Januškevičs (1972), onkologs;

Benita Krivicka-Užkurele (1972), morfoloǵe; 
Dzintars Ozoliņš (1967), mikrobiologs;

Haralds Plaudis (1979), kirurgs;

Jolanta Pupure (1983), farmakoloǵe;

Anda Slaidiṇa (1981), zobārste;

Kaspars Stāmers (1980), zobārsts;

Ainārs Stepens (1975), neirologs;

Signe Tomsone (1970), rehabilitoloǵe;

Ilva Trapiņa (1983), bioķīmiķe;

Andrejs Vanags (1976), ķirurgs;

Dace Zavadska (1976), pediatre.

\section{1}

Karīna Aksenoka (1974), mikrobioloǵe;

Arta Olga Balode (1948), mikrobioloǵe;

Zanda Daneberga (1976), ǵenētiķe;

Kristīne Ducena (1975), endokrinoloǵe;

Iveta Dzīvīte-Krišāne (1967), pediatre;

Jel̦ena Eglīte (1973), imunoloǵe;

Inese Gobiņa (1979), neiroloǵe;

Linards Grieznis (1977), zobārsts;

Iveta Ivdra (1977), dermatoveneroloǵe;

Iveta Jankovska (1980), zobārste;

Nataljja Jakušenko (1973), anestezioloğe reanimatoloğe;

Nataljja Kakurina (1963), interniste;

Helēna Kārkliṇa (1957), antropoloǵe;

Tālis Kauliņš (1963), anesteziologs reanimatologs;

Zita Krūmiņa (1951), ǵenētiķe;

Viktorija Ķēniņa (1977), neiroloǵe;

Zane Lauriņa (1980), zobārste;

Laura Logina (1976), plastikas ķirurǵe;

Inese Mārtiņsone (1975), arodpatoloǵe;

Ieva Mauliņa (1976), zobārste;

Iveta Mintāle (1965), kardioloǵe;

Jana Pavāre (1970), infekcioniste;

Pēteris Priedītis (1957), radiologs; 
Agrita Puzuka (1980), ǵenētiķe;

Oḷegs Sabel̦ninikovs (1977), anesteziologs reanimatologs;

Arta Strazdina (1956), radioloǵe;

Inga Stuķēna (1974), kardioloǵe;

Daina Šmite (1976), fizikālterapeite;

Edgars Vasil̨evskis (1968), anesteziologs reanimatologs;

Natālija Vedmedovska (1972), ginekoloǵe;

Ilona Viduskalne (1975), zobārste;

Olafs Volrāts (1968), bērnu ķirurgs;

Ieva Ziediņa (1975), nefroloǵe.

\section{Goda doktors (Doctor honoris causa)}

\section{2}

Ernests Gaudiņš (1922-2008), otolaringologs;

Romans Lācis (1946), kardioķirurgs;

Martins Ptoks (1955), otolaringologs (Vācija);

Sauļus Špokevičs (1957), dermatovenerologs (Lietuva).

\section{3}

Guna Dambīte (1922-2009), oftalmoloǵe;

Hans Kempers, fiziologs (Nīderlande);

Tomijs Linnejs (1945), bērnu nefrologs (Zviedrija);

Hanss Dītrihs Rohers, ķirurgs (Vācija);

Adrians Sugars (1947), ķirurgs (Lielbritānija);

Filips Andrē Šerperels, anesteziologs (Francija);

Klauss Pēters Tons, ķirurgs (Vācija);

Fēlikss Ungers (1946), kardioķirurgs (Austrija).

\section{4}

Kristīne Draviņa (1956), logopēde (Zviedrija);

Karstens Gundlahs (1943), mutes, sejas un žokḷu ķirurgs (Vācija);

Joahims Hartels (1945), mutes, sejas un žokḷu ķirurgs (Vācija);

Aleksandrs Kriščūns (1945), rehabilitologs (Lietuva);

Inga Brite Lindstrēma (1942), rehabilitolog̣e (Zviedrija);

Sorens Norgārds, rehabilitologs (Dānija); 
Sandra Olneja, rehabilitologie (Kanāda);

Jirgens Ošlīss, rehabilitologs (Vācija);

Malkolms Pēts, rehabilitologs (Kanāda);

Benedikte Steinrūde, rehabilitoloǵe (Dānija);

Klauss Šāršmits (1953), bērnu ķirurgs (Vācija);

Jānis Vētra (1959), biomehāniķis;

Egils Vēverbrants (1935), nefrologs (ASV).

\section{5}

Jans L,ubinskis, onkologs (Polija);

Mirdza Neidere (1933), orālpatoloǵe (ASV).

\section{7}

Osvalds Plēpis (1931-2011), otolaringologs;

Manfrēds Volfersdorfs, psihiatrs (Vācija).

\section{9}

Jans Lilja, zobārsts (Zviedrija);

Iveta Ozolanta (1948), biomehāniķe;

Pērs Skjelbreds, zobārsts (Norvēgija).

\section{0}

Jevgeñijs Matjakins (1943), onkologs (Krievija);

Peters Navrots, internists (Vācija);

Jānis Priedkalns (1934), morfologs;

Gotfrīds Rūmens, mikrobiologs (Zviedrija);

Kristaps Zariņš (1943), angioķirurgs (ASV);

Valdis Zatlers (1955), traumatologs ortopēds.

\section{1}

Johanness Beks (1957), radiologs (Vācija).

\section{Profesors}

\section{2}

Viesturs Baumanis (1942-2013), molekulārbiologs. 


\section{3}

Raisa Andrēziņa (1938), psihiatre;

Ģirts Briǵis (1953), sabiedrības veselības speciālists;

Rūta Care (1942), stomatoloǵe;

Gundega Knipše (1950), anatome;

Guna Laganovska (1962), oftalmoloǵe;

Jānis Sokolovs (1943), otolaringologs;

Ilga Urtāne (1950), stomatoloǵe.

\section{4}

Valdis Keris (1961), neiroķirurgs;

Juta Kroiča (1956), mikrobioloğe;

Viesturs Lāriņš (1947), sporta medicīnas speciālists;

Aivars Lejnieks (1957), internists;

Iveta Ozolanta (1948), biomehāniķe.

\section{5}

Ilze Akota (1964), stomatologe;

Viesturs Boka (1948), ķirurgs;

Jānis Jirgensons (1956-2007), kardiologs;

Sandra Lejniece (1963), hematologe;

Helēna Mikažāne (1948), reimatoloǵe;

Ruta Muceniece (1950), farmakoloǵe;

Jānis Ozoliṇš (1938-2008), neiroķirurgs;

Valdis Pīrāgs (1961), endokrinologs;

Juris Salaks (1961), medicīnas vēsturnieks.

2006

Baiba Rozentāle (1955), infekcioniste.

2007

Ingmārs Mikažāns (1971), dermatovenerologs;

Valda Staņeviča (1954), pediatre.

2008

Regīna Kleina (1952), patologanatome; 
Ināra Logina (1952), neiroloǵe;

Jurijs Markovs (1949), histologs;

Aivars Vētra (1956), rehabilitologs.

\section{9}

Inese Pontaga (1965), fizioloğe.

\section{1}

Andrejs Ërglis (1964), kardiologs;

Dainis Krieviņš (1967), angioķirurgs;

Andrejs Millers (1959), neirologs.

\section{Asociētais profesors}

\section{1}

Igors Aksiks (1948), neiroķirurgs;

Sandra Bērziṇa (1959), mikrobioloǵe;

Viesturs Boka (1948), ķirurgs;

Valentīna Gordjušina (1945), patoloǵe;

Uldis Kalniņš (1946-2004), kardiologs;

Aivars Lejnieks (1957), internists;

Ināra Logina (1952), neiroloğe;

Ingmārs Mikažāns (1971), dermatovenerologs;

Ruta Muceniece (1950), farmakoloǵe;

Iveta Ozolanta (1948), biomehānikse;

Andrejs Pavārs (1943), ķirurgs;

Valdis P̄̄rāgs (1961), internists;

Baiba Rozentāle (1955), infekcioniste;

Alfrēds Jānis Sīpols (1950), fiziologs;

Ojārs Teteris (1948), tiesu mediķis.

\section{2}

Ilze Akota (1964), stomatologe;

Ralfs Kolītis (1962), ķirurgs;

Sandra Lejniece (1963), hematologe;

Lidija Mauriņa (1939), rehabilitoloǵe; 
Helēna Mikažāne (1948), reimatoloğe;

Jānis Ozoliṇš (1938-2008), neirok̦irurgs;

Juris Pokrotnieks (1945), gastroenterologs.

\section{3}

Gunta Ancāne (1953), psihiatre;

Ināra Ančupāne (1950), dermatoveneroloǵe;

Mārcis Krūmiņš (1951), traumatologs ortopēds;

Ligija Ķīse (1957), otolaringologe;

Jānis Lācis (1935), kardiologs;

Viesturs Liguts (1950), toksikologs;

Inese Mihailova (1955), nefroloǵe;

Liāna Pl̦aviña (1960), anatome;

Inese Pontaga (1965), fizioloǵe;

Antonina Sondore (1936), anestezioloǵe reanimatoloǵe;

Valda Staņeviča (1954), pediatre;

Ivans Zagorskis (1939), internists;

Ints Zeidlers (1946), fizikālās medicīnas speciālists.

\section{4}

Brigita Aulika (1933-2016), vides veselības speciāliste;

Sarmīte Boka (1951), anatome;

Anda Brinkmane (1955), stomatologe;

Jānis Dobelis (1943), bērnu ķirurgs;

Valērija Groma (1958), histoloǵe;

Jāzeps Keišs (1942), infekcionists;

Rita Lugovska (1948), ǵenētiķe;

Inga Millere (1959), psihoterapeite;

Antons Skutelis (1939), farmakologs;

Aivars Vētra (1956), rehabilitologs.

\section{5}

Daina Andersone (1948), reimatoloǵe;

Harijs Čerņevskis (1946), nefrologs;

Egils Eglītis (1949), rehabilitologs; 
Arkādijs Gandzs (1944-2009), internists;

Dainis Krieviņš (1967), angioķirurgs;

Jevgeṇija Livdāne (1951), pediatre;

Aija Majore (1938), bioķīmiķe;

Biruta Mamaja (1945), anestezioloğe reanimatoloǵe;

Ardis Platkājis (1964), radiologs;

Elmārs Rancāns (1967), psihiatrs;

Egita Senakola (1955), stomatoloğe;

Aldis Vidžis (1954), stomatologs.

\section{6}

Genādijs Ambalovs (1945), ķirurgs;

Guna Jākobsone (1970), ortodonte;

Biruta Kupča (1939), psihiatre;

Jānis Ķ̄īsis (1956), dermatovenerologs;

Andrejs Millers (1959), neirologs;

Guntars Pupelis (1953), ķirurgs;

Una Sobolieva (1966), stomatoloǵe;

Genādijs Trofimovičs (1957), onkologs.

\section{7}

Guntis Bahs (1967), internists;

Uga Dumpis (1967), internists;

Andrejs Ërglis (1964), kardiologs;

Jurijs Karpovs (1956), kardiologs;

Alvils Krams (1960), pulmonologs;

Mārcis Leja (1964), gastroenterologs.

\section{8}

Staņislavs Jankovskis (1949), farmakologs;

Māra Kalniņa (1945), histoloǵe;

Erika Nagle (1947), ğenētiķe;

Mārīte Antra Ozoliņa (1944), arodpatoloğe;

Aivars Pētersons (1956), nefrologs;

Jānis Raibarts (1939), internists; 
Silvija Remberga (1949), pediatre;

Ludmila Zinčenko (1939), ǵenētiķe.

\section{9}

Arnis Eņgéelis (1953), bērnu ķirurgs;

Dzintars Mozgis (1958), sabiedrības veselības speciālists;

Dace Rezeberga (1960), ginekoloǵ;

Pēteris Tretjakovs (1958), fiziologs;

Anita Vētra (1953), rehabilitoloğe.

\section{0}

Inese Folkmane (1961), nefroloǵe;

Oskars Kalējs (1957), kardiologs;

Džanna Krūmiņa (1957), anatome;

Vladimirs Kuzṇecovs (1944), psihiatrs;

Aldis Puķīis (1966), gastroenterologs;

Igors Solomatins (1958), oftalmologs.

\section{1}

Ilze Grope (1967), pediatre;

Ieva Henkuzena (1961), zobārste;

Arnolds Jezupovs (1971), ķirurgs;

Andris Jumtiņš (1959), ortopēds;

Angelika Krūmiņa (1970), infekcioniste;

Gustavs Latkovskis (1971), kardiologs;

Edvīns Miklaševičs (1955), molekulārbiologs;

Ženija Roja (1947), arodpatoloǵe;

Ilze Štrumfa (1974), patoloǵe;

Ilze Vīberga (1963-2016), ginekoloǵe;

Guntis Žìgurs (1953), stomatologs. 


\section{Latvijas Zinātṇu akadēmijas \\ īstenais loceklis}

\section{1}

Arnis Vīksna (1942), medicīnas vēsturnieks.

\section{3}

Jekaterina Ērenpreisa (1945), molekulārbioloǵe.

\section{6}

Jānis Gardovskis (1955), ķirurgs.

\section{8}

Ruta Muceniece (1950), farmakologe.

\section{0}

Nikolajs Sjakste (1955), bioķīmiķisis.

\section{Latvijas Zinātṇu akadēmijas korespondētājloceklis}

\section{1}

Ruta Muceniece (1950), farmakoloǵe.

\section{3}

Ludmila Vīksna (1946), infekcioniste.

\section{4}

Uldis Kalniņš (1946-2004), kardiologs; Modra Murovska (1949), virusoloǵe.

\section{5}

Ingrīda Rumba (1959), pediatre;

Nikolajs Sjakste (1955), bioķīmiķis.

\section{6}

Igors Aksiks (1948), neiroķirurgs. 
Andrejs Ërglis (1964), kardiologs.

\section{9}

Dace Gardovska (1952), pediatre; Valdis Pīrāgs (1961), internists.

2010

Aivars Lejnieks (1957), internists.

\section{1}

Dainis Krieviņš (1967), angioķirurgs.

\section{Latvijas Zinātṇu akadēmijas goda loceklis}

2006

Viesturs Baumanis (1942-2013), molekulārbiologs.

\section{1}

Aina Nagobada-Ābola (1920), zobārste.

\section{Valsts emeritētais zinātnieks}

\section{1}

Kārlis Ēriks Arons (1933-2005), medicīnas vēsturnieks;

Jānis Baltkājs (1935), farmakologs;

Juris Bērziņš (1928), neirologs;

Alfrēds Miltiņš (1939), dermatovenerologs;

Anita Ozoliņa (1929), biok̦īmiķe.

\section{2}

Aris Lācis (1936), kardioķirurgs;

Ivars Siliņš (1931), internists;

Leonids Sluckis (1927-2013), bioķīmiķis. 
Indulis Buiksis (1933), histologs;

Juris Leja (1938), patofiziologs;

Renāte Ligere (1936), endokrinoloǵe;

Lidija Maksimova (1929), bioķīmiķe;

Māris Mihelsons (1936-2014), ķirurgs;

Rafails Rozentāls (1937), transplantologs;

Antoņina Sondore (1936), anestezioloǵe reanimatoloǵe;

Larisa Terentjeva (1928-2013), interniste;

Ideja Valıkova (1931-2013), oftalmoloǵe.

\section{4}

Arnolds Muižulis (1922-2008), traumatologs ortopēds;

Ilga Zītare (1929-2015), onkoloǵe.

\section{5}

Brigita Aulika (1933-2016), vides veselības speciāliste; Imants Detlavs (1930-2009), neirologs;

Guna Feldmane (1934), virusologe;

Andris Ferdats (1941), virusologs;

Alfrēds Polis (1932-2013), filozofs;

Haralds Voskis (1928-2011), ķirurgs.

\section{6}

Dzidra Branta (1927), dermatoveneroloǵe;

Rūta Brūvere (1935), mikrobioloǵe;

Vaira İrisa Kalnina (1941), virusoloǵe;

Astrīda Krūmiņa (1940), ġenētiķe;

Jānis Lasovskis (1937), stomatologs;

Svetlana Thora (1939), angioķirurğe;

Ingolfs Žukovskis (1938-2015), transfuziologs.

\section{7}

Bencions Cerl̦uks (1913-2009), traumatologs ortopēds;

Laila Feldmane (1937-2014), patoloǵe; 
Valija Pakalne (1928), stomatoloǵe;

Osvalds Plēpis (1931-2011), otolaringologs;

Aija Žileviča (1940), mikrobioloǵe.

\section{8}

Svetlana Andrejeva (1936), ginekoloǵe;

Biruta Barkāne (1935), stomatoloǵe;

Anda Dauvarte (1932), interniste;

Irēna Rēvele (1927), stomatoloǵe;

Rasma Vìtoliņa (1939), farmakoloǵe.

\section{Saeimas deputāts}

\section{2}

Ingrīda Circene (1956), ginekoloǵe;

Ol̦egs Deņisovs (1966), ķirurgs;

Aleksandrs Golubovs (1959-2010), otolaringologs;

Sarmīte Ķikuste (1962), ginekoloǵe;

Vitālijs Orlovs (1964), neirologs;

Leopolds Ozolinšs (1937), traumatologs ortopēds;

Aigars Pētersons (1959), bērnu ķirurgs;

Jānis Straume (1962), internists;

Jānis Strazdiņš (1941), narkologs;

Kārlis Strēlis (1943), sporta medicīnas speciālists;

Viesturs Šiliņš (1950), ftiziopneimonologs.

\section{4}

Uldis Briedis (1942), ķirurgs;

Valdis Ģīlis (1954), ķirurgs.

2005

Igors Aleksandrovs (1960), ķirurgs. 


\section{Saeimas deputāts}

2006

Uldis Briedis (1942), ķirurgs;

Ingrīda Circene (1956), ginekoloǵe;

Gundars Daudze (1965), anesteziologs reanimatologs;

Ol̦egs Deniisovs (1966), ķirurgs;

Aleksandrs Golubovs (1959-2010), otolaringologs;

Valdis Ģīlis (1954), ķirurgs;

Sarmīte Ķikuste (1962), ginekologie;

Vitālijs Orlovs (1964), neirologs;

Leopolds Ozoliņš (1937), traumatologs ortopēds;

Jānis Strazdiṇš (1941), narkologs.

\section{9}

Igors Aleksandrovs (1960), ķirurgs.

\section{Saeimas deputāts}

2010

Ingrīda Circene (1956), ginekologé;

Gundars Daudze (1965), anesteziologs reanimatologs;

Vitālijs Orlovs (1964), neirologs;

Jānis Strazdiņš (1941), narkologs.

\section{Saeimas deputāts}

\section{1}

Vitālijs Orlovs (1964), neirologs;

Romualds Ražuks (1955), neiroķirurgs;

Valdis Zatlers (1955), kiirurgs, veselības aprūpes vadītājs.

\section{Veselības ministrs}

2002

Āris Auders (1962), neiroķirurgs. 
Ingrīda Circene (1956), ginekoloǵe.

\section{4}

Rinalds Muciņš (1975), jurists;

Gundars Bērziņš (1959), inženieris.

2007

Vinets Veldre (1971), veterinārārsts;

Ivars Eglītis (1959), veselības aprūpes vadītājs.

2009

Baiba Rozentāle (1955), infekcioniste.

2010

Didzis Gavars (1966), laboratorijas ārsts;

Juris Bārzdiņš (1966), veselības aprūpes vadītājs.

\section{1}

Ingrīda Circene (1956), ginekoloǵe.

\section{Saeimas priekšsēdētājs}

2007

Gundars Daudze (1965), anesteziologs reanimatologs.

\section{Valsts prezidents}

\section{7}

Valdis Zatlers (1955), ķirurgs, veselības aprūpes vadītājs.

Arnis Vīksna, Dr. med., profesors

Paula Stradiña Medicīnas vēstures muzejs

arnis.viksna@mvm.lv 